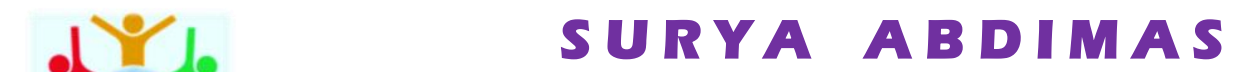

Vol. 5 No. 4 (2021) pp. 519 - 531

Available online at: http://jurnal.umpwr.ac.id/index.php/abdimas/index

p-ISSN: 2580-3492 e-ISSN: 2581-0162

\title{
Program Literasi Hijau dan Pengadaan Air Bersih untuk Masyarakat
}

\section{${ }^{1}$ Novi Eka Susilowati $\varangle,{ }^{1}$ Ariva Luciandika, ${ }^{1}$ Dewi Ariani, ${ }^{2}$ Muhammad Hambali}

\section{Universitas Negeri Malang}

Jl. Semarang 5 Malang 65145 Jawa Timur Indonesia

Universitas Brawijaya

Jl. Mayjen Haryono 169, Lowokwaru, Malang 65145, Jawa Timur, Indonesia

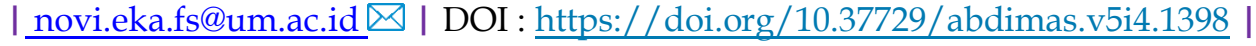

\begin{abstract}
Abstrak
Permasalahan utama mitra pengabdian kepada masyarakat ini adalah sulitnya pemenuhan air bersih untuk kebutuhan sehari-hari masyarakat. Padahal, di desa tersebut sebenarnya terdapat beberapa sumber air yang dapat dimanfaatkan oleh masyarakat. Kesulitan dalam memenuhi air bersih untuk kebutuhan sehari-hari masyarakat tersebut disebabkan oleh (1) rendahnya penguasaan ilmu pengetahuan dan teknologi masyarakat sehingga mereka belum menemukan solusi yang efektif, efisien, murah, dan berkelanjutan untuk mengalirkan air; (2) letak sumber air yang berada di bawah perkampungan warga sehingga warga kesulitan untuk mengalirkan air dari tempat yang rendah ke tempat yang lebih tinggi; dan (3) rendahnya tingkat ekonomi masyarakat sehingga mereka tidak memiliki dana yang cukup untuk mengadakan alat teknologi untuk mengalirkan air. Selain itu, masalah yang dihadapi mitra adalah kurang maksimalnya kesadaran masyarakat terhadap pelestarian lingkungan. Kegiatan pengabdian ini bertujuan membantu menyediakan air bersih dengan menggunakan pompa hidram dan memberikan literasi hijau kepada masyarakat untuk memaksimalkan kesadaran melestarikan lingkungan. Metode yang dilakukan adalah sosialisasi, pembuatan alat dan bahan, pendamingan, dan evaluasi. Hasil kegiatan pengabdian menunjukkan bahwa pompa hidram efektif digunakan untuk mengalirkan air di pedesaan yang sumber airnya berada jauh di bawah lokasi perkampungan warga. Selain itu, pada kegiatan ini dilakukan pula untuk memberikan literasi hijau kepada masyarakat sehingga kelestarian sumber air dapat terjaga.
\end{abstract}

Kata Kunci: Pompa hidram, Air bersih, Literasi hijau, Pelestarian lingkungan, Teknologi

(7) (8) This work is licensed under a Creative Commons Attribution-NonCommercial 4.0 International License

\section{Pendahuluan}

\subsection{Analisis Situasi}

Dalam pengabdian ini, masyarakat yang menjadi sasarannya adalah masyarakat desa Wonorejo, Kecamatan Lumbang, Kabupaten Pasuruan. Dilihat dari letak geografis, Desa Wonorejo terletak di lereng Gunung Bromo sebelah utara timur dengan ketinggian elevasi antara 800-2000 meter di atas permukaan laut (mdpl). Dengan letak geografis pada ketinggian dengan kontur yang miring, tetapi memiliki tingkat kesuburan yang cukup, daerah ini termasuk memiliki produktivitas dalam menghasilkan tanaman holtikultura yang beragam, terutama sayuran seperti kentang, kubis, dan bawang daun. Keadaan georafis yang demikian menjadikan sebagian besar masyarakat di daerah tersebut menggantungkan penghasilannya dengan bertani. Namun demikian, tidak semua masyarakat memiliki tanah sendiri untuk digarap menjadi lahan pertanian. 
Sebagian besar masyarakah menggarap lahan yang dimiliki oleh Perhutani dengan menyewa (mengontrak tanah milik Perhutani). Ditinjau dari segi pendidikan, sebagian besar masyarakat desa ini berpendidikan SD. Hanya generasi muda saat ini yang sudah mulai mengenyam pendidikan SMP karena sudah disediakan SMP kelas jauh di desa tersebut. Sebagian kecil di antara generasi muda desa ini melanjutkan pendidikan ke pondok "di bawah" (tidak di area gunung).

Selain memiliki tingkat kesuburan yang cukup tinggi, masyarakat petani Desa Wonorejo memiliki tantangan dalam mengolah lahannya. Tantangan yang paling besar adalah penyediaan benih tanaman, obat pembasmi hama, dan kekurangan air ketika musim kemarau. Air sebagai kebutuhan utama untuk kehidupan masyarakat dan pertanian, hingga saat ini masih sulit didapatkan oleh warga dan hingga saat ini belum ada usaha dan solusi yang ditemukan oleh masyarakat. Untuk kebutuhan air bersih, hampir sepanjang tahun permasalah ini melanda semua masyarakat di Desa Wonorejo.

Jumlah sumber mata air di desa ini sangat terbatas yang dipengaruhi terletak di pegunungan dengan kemiringan yang cukup curam. Dalam observasi yang dilakukan, terdapat sekitar tujuh mata air dengan debit sekitar 3-120 liter per menit. Dari jumlah tersebut, dua mata air memiliki debit yang cukup besar yang terletak di sungai lereng pegunungan dengan posisi di bawah perkampungan. Sumber mata air tersebut adalah Sumber Glongsor yang memiliki debit sekitar 120 liter per menit terletak sekitar 250 meter di bawah perkampungan dan sumber mata air Petungroto debit sekitar 100 lpm yang terletak sekitar 75 meter di bawah perkampungan.

Program pipanisasi air bersih sebelumnya sudah pernah dilakukan oleh pihak pemerintahan desa. Air hasil pipanisasi berasal dari sumber-sumber kecil di hutan atas desa. Namun demikian, debit air yang dihasilkan sangat minim sehingga belum memenuhi kebutuhan dasar untuk memasak dan kebersihan, seperti mandi, cuci, dan kakus. Dengan jumlah air yang terbatas tersebut, masyarakat harus rela mengantri dalam waktu yang cukup lama, bahkan dalam suatu antrian terkadang bisa 50 sampai 100 jerigen. Pada kondisi tertentu, misalnya untuk kebutuhan masjid, masyarakat membeli air dalam jerigen yang diambil dari dua desa yang ada di bawah (desa Umbulanterdapat mata air Umbulan) sekitar 15 kilometer. Masyarakat pun kadang harus mengantre air hingga lewat tengah malam. Bahkan, kadangkala aktivitas mengantre air harus dibarengi dengan pertengkaran antarwarga yang mengantre karena berebut giliran mengalirkan air ke jurigen mereka. Padahal, akses terhadap air bersih merupakan parameter mutlak terciptanya kualitas hidup yang baik (Audah, et al., 2019). Hasil observasi awal yang telah dilakukan oleh tim PkM terhadap kondisi masyarakat selama mengantre air seperti ditunjukkan pada Gambar 1.
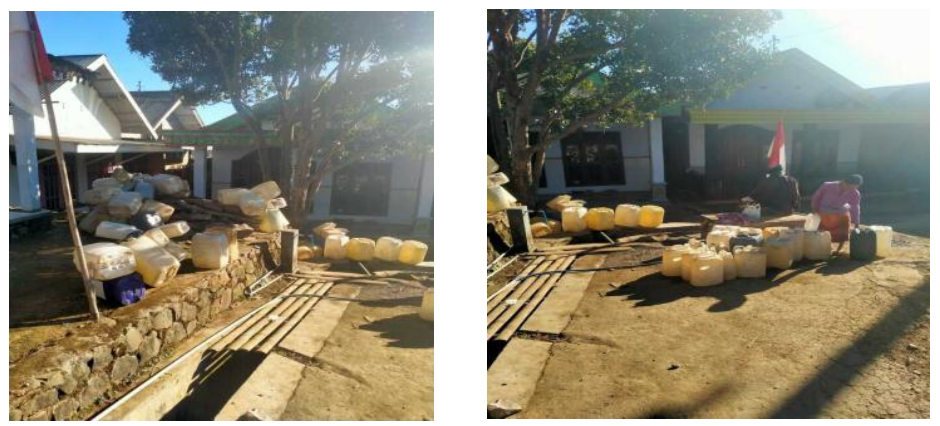

Gambar 1. Kondisi antrean jurigen untuk mencari air bersih 
Kajian terdahulu terkait kebutuhan masyarakat pada air bersih dilaksanakan oleh (Kurniawan, et al., 2018) telah melakukan pengkajian terhadap kebutuhan masyarakat Kecamatan Lumbang. Analisis yang dilakukan meliputi analisis kebutuhan debet air per desa, jalur aliran air, hingga RAB kebutuhan penyediaan sarana dan prasarana pengairan di masing-masing desa (Kurniawan, et al., 2018). Sayangnya, dari dua belas desa yang ada di Kecamatan Lumbang, hanya sebelas desa yang analisis, sedangkan satu desa yang lain tidak dianalisis. Desa tersebut adalah desa Wonorejo. Oleh karena itu, desa ini belum mendapat "sentuhan" analisis ilmiah maupun teknologi yang tepat dan memadai selama ini.

\subsection{Permasalahan Mitra}

Permasalahan utama mitra pengabdian kepada masyarakat ini adalah sulitnya pemenuhan air bersih untuk kebutuhan sehari-hari masyarakat. Padahal, di desa tersebut sebenarnya terdapat beberapa sumber air yang dapat dimanfaatkan oleh masyarakat. Kesulitan dalam memenuhi air bersih untuk kebutuhan sehari-hari masyarakat tersebut disebabkan oleh faktor-faktor berikut ini.

a. Rendahnya penguasaan ilmu pengetahuan dan teknologi masyarakat sehingga mereka belum menemukan solusi yang efektif, efisien, murah, dan berkelanjutan untuk mengalirkan air.

b. Letak sumber air yang berada di bawah perkampungan warga sehingga warga kesulitan untuk mengalirkan air dari tempat yang rendah ke tempat yang lebih tinggi.

c. Rendahnya tingkat ekonomi masyarakat sehingga mereka tidak memiliki dana yang cukup untuk mengadakan alat teknologi untuk mengalirkan air.

d. Rendahnya literasi masyarakat dalam menjaga dan mengelola lingkungan di sekitar sumber air sehingga pemanfaatan, penjagaan, dan pelestarian air tidak dilakukan secara optimal. Padahal, penjagaan kelestarian lingkungan sangat berpengaruh terhadap keberlangsungan air tanah (Anggraeni, 2019).

e. Situasi politik di desa yang menyebabkan pemenuhan kebutuhan air bersih tidak menjadi prioritas utama program pemerintah desa. Kondisi ini sejalan dengan pandangan (Suyeno, et al., 2014) yang menyebutkan bahwa penyediaan air bersih juga dipengaruhi oleh kondisi politik pemegang kebijakan.

f. Letak demografi desa yang jauh dan sulit dijangkau sehingga tidak banyak pihak luar yang datang ke desa tersebut untuk memberikan bantuan.

g. Akses menuju desa yang harus melewati area yang rawan premanisme (begal) sehingga membuat pihak luar enggan mendatangi desa tersebut (Fatikh \& Panuju, 2018).

Berdasarkan identifikasi masalah utama dan penyebabkan, disepakati dengan mitra bahwa masalah yang akan dipecahkan bersama adalah pengadaan air bersih yang dilakukan dengan cara mengalirkan air dari sumber-sumber air di wilayah desa tersebut. Pengelolaan sumber daya air yang tepat dan serius serta mampu memenuhi kebutuhan masyarakat mutlak diperlukan (Fakhrina, 2013). Untuk memudahkan pengaliran air, digunakan teknologi pompa hidram yang dapat digunakan untuk mengalirkan air dari sumber air yang berada di bawah perkampungan warga. Teknologi pompa hidram ini tepat digunakan untuk masyarakat pedesaan (Herlambang \& Wahjono, 2006) serta meringankan beban masyarakat yang memiliki lahan di atas sumber air (Kuncoro \& Wangi, 2021). 


\subsection{Solusi dan Target}

Pada prinsipnya, penyediaan air bersih diutamakan bagi masyarakat yang belum memiliki akses terhadap air bersih (Kodoatie, 2005). Oleh karena itu, dilakukan kegiatankegiatan berikut untuk membuka akses air bersih bagi masyarakat. Berdasarkan permasalahan dan faktor penyebab yang telah diuraikan, dirumuskan solusi dan target luaran seperti disajikan pada Tabel 1.

Tabel 1. Permasalahan mitra, solusi, dan target luaran

\section{Permasalahan Mitra}

Kekurangan air bersih untuk kebutuhan seharihari dan kebutuhan pertanian masyarakat Ketidakpahaman/ketidakt ahuan masyarakat tentang teknologi yang dapat digunakan untuk mengalirkan air dari tempat yang lebih rendah ke tempat yang lebih tinggi

Rendahnya kesadaran masyarakat terhadap upaya untuk memanfaatkan, menjaga, dan melestarikan sumber air yang ada di wilayah desa mereka

\section{Solusi}

Mengalirkan air dari sumber yang ada di wilayah desa

Memanfaatkan teknologi pompa hidram untuk mengalirkan air dari tempat yang lebih rendah ke tempat yang lebih tinggi

Memberikan penyuluhan tentang pentingnya memanfaatkan, menjaga, dan melestarikan sumber air yang ada di wilayah desa mereka

\section{Target Luaran}

Air yang teralirkan ke rumah-rumah warga dan tempat ibadah

Teknologi pompa hidram yang benar-benar beroperasi untuk mengalirkan air ke rumahrumah warga dan tempat ibadah

Warga memiliki pemahaman tentang upaya penghijauan kembali dan menjaga kelestarian di sekitar sumber air

\section{Metode}

Kegiatan pengabdian ini akan dilakukan di desa Wonorejo, kecamatan, Lumbang, kabupaten Pasuruan. Desa ini berjarak $75 \mathrm{~km}$ dari kota Malang dan berjarak $29 \mathrm{~km}$ dari kota Pasuruan, semntara itu jika dari kecamatan Lumbang berjarak $30 \mathrm{~km}$. Desa ini bisa dijangkau dengan motor maupun mobil dengan lama perjalanan kurang lebih 3 jam dari kota Malang dan 1 jam dari kota Pasuruan. Secara geografis, batas wilayah desa Wonorejo adalah sebagai berikut: (a) sebelah barat berbatasan dengan desa Pusung Malang, kecamatan Puspo; (b) sebelah timur berbatasan wilayah hutan Perhutani; (c) sebelah utara desa Kronto, kecamatan Lumbang; dan (d) sebelah selatan berbatasan hutan Perhutani. Desa Wonorejo berada di ketinggian 1138 mdpl dan merupakan desa tertinggi di Kabupaten Pasuruan. Untuk mencapai desa tersebut, jalur yang bisa ditempuh adalah melalui jalur desa Winongan. Peta lokasi kegiatan PkM ini dapat ditunjukkan pada Gambar 2. 


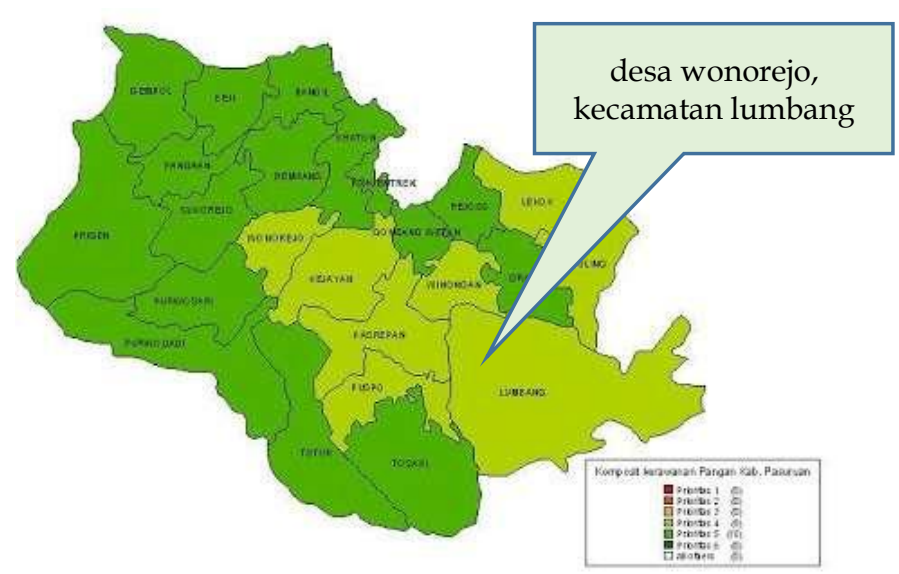

Gambar 2. Peta desa Wonorejo, kecamatan Lumbang, kabupaten Pasuruan

Kegiatan pengabdian ini bertujuan untuk memberi bantuan masyarakat desa dalam mengalirkan air bersih ke area perkampungan dengan menggunakan teknologi sekaligus untuk menumbuhkan kesadaran masyarakat akan pentingnya memanfaatkan, menjaga, dan melestarikan sumber daya alam yang ada di sekitar mereka.

Pada saat kegiatan pengabdian berlangsung, masyarakat diberi pemahaman tentang deskripsi, cara kerja, dan cara perawatan/pemeliharaan pompa hidram. Masyarakat juga diberi pemahaman tentang cara mengalirkan air dari tempat yang lebih rendah ke tempat yang lebih tinggi. Selain itu, masyarakat juga diberi pemahaman tentang pengelolaan air ketika air sudah berhasil dialirkan ke perkampungan warga. Pemahaman-pemahaman yang disampaikan ini diharapkan dapat menjadi bekal bagi warga masyarakat dalam mengalirkan dan mengelola air yang sudah mengalir ke perkampungan. Dengan demikian, setelah kegiatan pengabdian selesai dilaksanakan, warga dapat mengoperasikan pompa hidram sendiri dan mengelola air yang sudah mengalir.

Dalam jangka panjangnya, bekal informasi tentang pengaliran air dengan menggunakan pompa hidram diharapkan dapat menjadi inspirasi bagi masyarakat untuk mengalirkan air dari sumber-sumber lain yang ada di wilayah desa tersebut. Pada skala yang lebih luas, air yang sudah dapat dialirkan ke depannya tidak hanya dapat dimanfaatkan untuk mencukupi kebutuhan sehari-hari warga dan rumah ibadah, melainkan juga dapat dimanfaatkan untuk pertanian dan peternakan mereka.

Mengingat masih ada sumber-sumber air lain yang belum dieksplor, pemberian informasi mengenai teknologi pompa hidram diharapkan dapat memberikan petunjuk bagi masyarakat untuk mengalirkan air dari sumber-sumber air lain yang sebelumya belum pernah dimanfaatkan. Dengan demikian, ke depannya kebutuhan air bersih masyarakat dapat tercukupi dan taraf hidup serta kesehatan masyarakat dapat meningkat. Konflik antarwarga karena masalah air pun diharapkan dapat diredam dan diselesaikan. Adapun metode pelaksanaan program ini dijabarkan sebagai berikut, disajikan pada Tabel 1. 
Tabel 2 Permasalahan mitra dan metode pemecahan

\begin{tabular}{llll}
\multicolumn{1}{c}{$\begin{array}{l}\text { Permasalahan } \\
\text { Mitra }\end{array}$} & \multicolumn{2}{c}{ Metode } \\
Kekurangan air & - & $\begin{array}{l}\text { Berkoordinasi dengan pimpinan dan masyarakat desa untuk } \\
\text { merencanakan kegiatan pengaliran air. }\end{array}$ \\
bersih untuk & - $\begin{array}{l}\text { Memperkenalkan teknolog pompa hidram dalam mengalirkan air dari } \\
\text { kebutuhan }\end{array}$ & tempat yang lebih rendah ke tempat yang lebih tinggi. \\
sehari-hari dan & & Membuat peta pengaliran air. \\
kebutuhan & - & \\
pertanian & - Membuat rancangan kerja. \\
masyarakat & - Membagi tugas pengaliran air. \\
& - Melaksanakan kerja pengaliran air.
\end{tabular}

Pada kegiatan ini, mitra berpartisipasi dalam bergotong royong melakukan pemasangan pompa, pemasangan pipa, penyiapan tandon, dan pembuatan infrastruktur pengaliran air ke rumah-rumah warga dan tempat ibadah.

Ketidakpahaman / ketidaktahuan masyarakat tentang teknologi yang dapat digunakan untuk mengalirkan air dari tempat yang lebih rendah ke tempat yang lebih tinggi

\section{Rendahnya}

kesadaran

masyarakat terhadap upaya untuk memanfaatkan, menjaga, dan melestarikan sumber air yang ada di wilayah desa mereka
- Memberi pemahaman kepada masyarakat tentang teknologi pompa hidram.

- Memberikan penjelasan tentang cara kerja pompa hidram.

- Memberikan penjelasan tentang cara perawatan/ pemeliharaan pompa hidram.

Pada kegiatan ini, mitra berpartisipasi aktif-reseptif sebagai subjek yang menerima penjelasan tentang segala deskripsi pompa hidram.

\section{Hasil dan Pembahasan}

Desa Wonorejo yang berada di lereng Gunung Bromo yang ketinggian di atas 1000 mdpl memiliki keterbatasan sumber daya air yang mengalir dari atas, salah satu sumber mata air potensial yang dapat dimanfaatkan meskipun terletak jauh di bawah pemukiman/ desa. Untuk memanfaatkan sumber mata air tersebut, banyak temuan teknologi yang bisa diterapkan. Misalnya penggunaan pompa listrik atau diesel. Penggunaan pompa listrik dapat diterapkan, tetapi memiliki konsekuensi biaya yang sangat tinggi untuk membeli pompa dengan spesifikasi khusus dan biaya operasional 
(Zulfiar, 2020). Dengan biaya yang tinggi, masyarakat akan merasa sangat berat. Untuk mengatasi permasalahan tersebut, dibutuhkan usaha dan teknologi tepat guna agar dapat membantu masyarakat mengurangi biaya yang harus di keluarkan atau bahkan bila memungkinkan tidak mengeluarkan biaya. Salah satu teknologi tepat guna yang bisa diterapkan adalah "Pompa Hidram" atau disebut juga Hidraulic Ram Pump. Teknologi tersebut sudah banyak digunakan dan dimanfaatkan oleh masyarakat, terutama masyarakat yang berada di pelosok daerah pegunungan yang kondisi geografisnya sangat sulit.

\subsection{Gambaran Umum Teknologi Pompa Hidram yang Digunakan dalam Pengabdian \\ a. Deskripsi Umum Pompa Hidram}

Pompa hidram merupakan salah satu pompa air yang ramah lingkungan dan hemat energi. Prinsip kerja pompa hidram adalah memompa dengan menggunakan tenaga momentum air (water hammer) untuk menaikkan air. Oleh karena itu, pompa hidram salah satu pompa air yang tidak menggunakan bahan bakar minyak atau pun energi listrik. Pompa hidram memanfaatkan tenaga aliran yang jatuh dari sumber air yang elevasinya lebih tinggi untuk menghasilkan suatu gaya tekanan dan gaya tekanan itu digunakan untuk memompa sebagian dari air itu ke tempat yang lebih tinggi.

Pada berbagai kondisi, pompa hidram memiliki keuntungan jika dibandingkan dengan pompa jenis lainnya. Diantara keuntungan tersebut adalah tidak dibutuhkannya bahan bakar atau tambahan tenaga dari sumber lain, tidak memerlukan pelumasan, bentuk dan desainnya sederhana, biaya bahan dan pembuatan serta pemeliharaannya murah, dan tidak membutuhkan keterampilan teknik tinggi untuk membuatnya. Pompa ini dapat bekerja dalam dua puluh empat jam per hari. Pompa ini juga dapat bertahan hingga bertahun-tahun tanpa berhenti bekerja. Selain itu, pompa hidram dalam bekerja tidak menimbulkan kebisingan dan ramah lingkungan. Hal tersebut sejalan dengan program pemerintah dalam hal energi: "energi baru terbarukan" (green renewable energy) (Herlambang \& Wahjono, 2006; Pribadi, 2019).

\section{b. Prinsip Dasar dan Mekanisme Kerja Pompa Hidram}

Kinerja dari pompa hidram dipengaruhi beberapa parameter, antara lain tinggi jatuh air dari penampungan (reservoir) ke pompa, diameter pipa yang mempengaruhi besar pompa, jenis pipa yang menentukan ketahan pakai, karakteristik katub buang, panjang pipa inlet, panjang pipa outlet, dan panjang pipa pada katub pembuangan (Utomo \& Supardi, 2015). Parameter tersebut harus dihitung agar gaya yang bekerja dalam pompa bisa kompatibel.

Pompa hidram memiliki cara kerja mengubah energi kinetis aliran air menjadi tekanan dinamik dan akibatnya menimbulkan palu air (water hammer) sehingga menimbulkan tekanan tinggi dalam pipa (Utomo \& Supardi, 2015). Dengan mengusahakan supaya katub pembuang (waste valve) dan katub air keluar (delivery valve) terbuka dan tertutup secara bergantian, maka tekanan dinamik diteruskan sehingga tekanan inersia yang terjadi dalam pipa pemasukan memaksa air naik ke pipa penghisap. Adapun gejala palu air yang terjadi aliran dalam pipa dengan kecepatan $\left(v_{1}\right)$ secara tibatiba dihentikan akan menyebabkan terhentinya aliran air sehingga kecepatan $\left(v_{2}\right)$ menjadi nol maka timbul gaya $F$. Prinsip kerja pompa hidram ditunjukkan pada Gambar 3. 


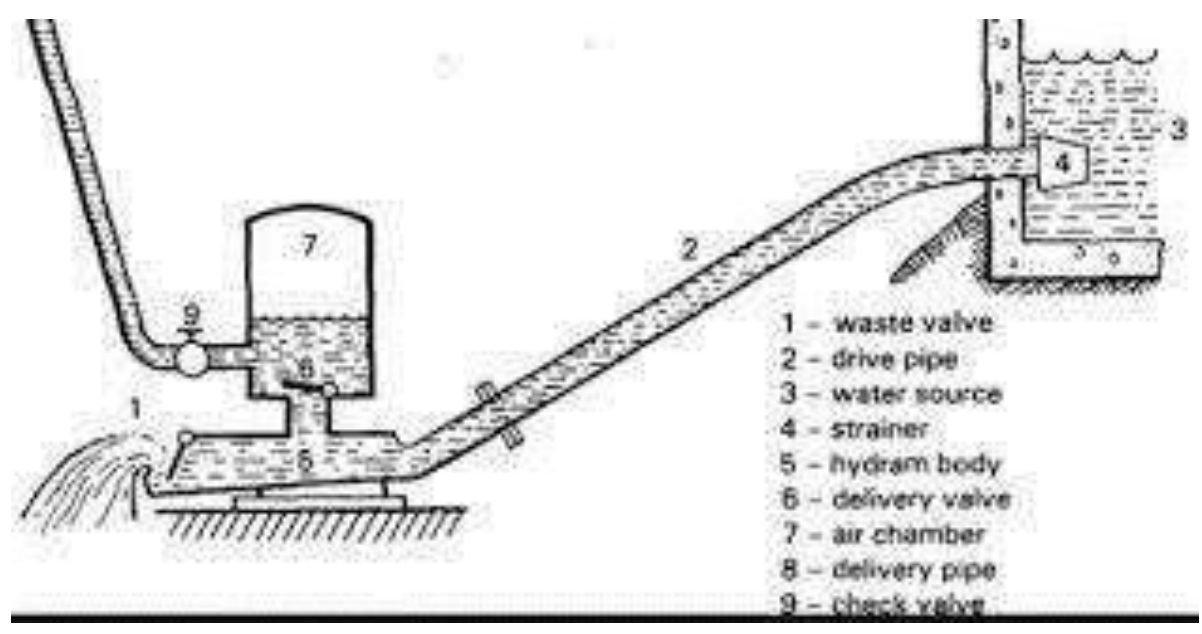

Gambar 3. Prinsip kerja pompa hidram

Dalam prinsip kerjanya, hidram memanfaatkan gravitasi yang mengalirkan air dari tempat yang lebih tinggi sehingga akan menciptakan energi dari hantaman air yang menabrak faksi air lainnya untuk mendorong ke tempat yang lebih tinggi. Untuk mendapatkan energi potensial dari hantaman air diperlukan syarat utama yaitu harus ada terjunan air yang dialirkan melalui pipa dengan beda tinggi elevasi dengan pompa hidram minimal 1 meter.

Syarat utama kedua adalah sumber air harus kontinu dengan debet minimal 7 liter per menit (Widarto \& Sudarto, 2000). Kunci utama pompa hidram dalam bekerja adalah pada dua buah klep, yaitu: klep pembuangan dan klep pengisap (Utomo \& Supardi, 2015). Air masuk dari terjunan melalui pipa A, klep pembuangan terbuka sedangkan klep pengisap tertutup. Air yang masuk memenuhi rumah pompa mendorong ke atas klep pembuangan hingga menutup. Dengan tertutupnya klep pembuangan mengakibatkan seluruh dorongan air menekan dan membuka klep pengisap dan air masuk memenuhi ruang dalam tabung kompresi di atas klep pengisap.

Pada volume tertentu pengisian air dalam tabung kompresi optimal, massa air dan udara dalam tabung kompresi akan menekan klep pengisap untuk menutup kembali, pada saat yang bersamaan sebagian air keluar melalui pipa B. Dengan tertutupnya kedua klep, maka aliran air dalam rumah pompa berbalik berlawanan dengan aliran air masuk, diikuti dengan turunnya klep pembuangan karena arah tekanan air tidak lagi ke klep pembuangan tetapi berbalik ke arah pipa input A. Di sinilah Hantaman -ram- palu air (water hammer) itu terjadi, di mana air dengan tenaga gravitasi dari terjunan menghantam arus balik tadi, 2/3 debit keluar lubang pembuangan, sementara yang 1/3 debit mendorong klep pengisap masuk ke dalam tabung pompa sekaligus mendorong air yang ada dalam tabung pompa untuk keluar melalui pipa output B. Energi hantaman yang berulang-ulang mengalirkan air ke tempat yang lebih tinggi (Utomo \& Supardi, 2015).

\subsection{Hasil Pelaksanaan Pengabdian kepada Masyarakat}

Pelaksanaan kegiatan pengabdian kepada masyarakat ini dilakukan dengan cara memberikan prasarana pengaliran air bagi masyarakat sasaran. Penyediaan prasarana penting untuk dilakukan karena prasarana dapat memberi dampak terhadap peningkatan taraf dan mutu kehidupan masyarakat, pola pertumbuhan, dan prospek perkembangan ekonominya (Sukamta, et al., 2019). Adapun penyediaan prasarana yang dilakukan adalah dengan pemberian alih teknologi pompa hidram kepada masyarakat. Alih teknologi 
dilakukan dengan cara memberikan pemahaman tentang pompa hidram, melatih masyarakat sasaran membuat pompa hidram, melatih masyarakat memasang pompa hidram beserta instalasinya, dan melatih masyarakat merawat pompa hidram. Selain itu, karena pompa hidram adalah pompa air yang membutuhkan debet air yang berkelanjutan, tim pengabdian juga memberi pemahaman kepada masyarakat untuk menjaga kelestarian lingkungan air sumber air tetap terjaga dan mampu terus memberi suplai air. Kegiatan pengabdian kepada masyakat ini lebih detailnya dibajarkan berikut ini. Pertama, koordinasi dengan pihak mitra. Koordinasi dilakukan dengan pihak mitra yang terdiri atas sekretaris desa, dan warga yang dilibatkan dalam program ini. Dalam kegiatan ini, dirumuskan bersama langkah-langkah yang akan dilakukan untuk melaksanakan kegiatan pengabdian kepada masyarakat ini.

Kedua, penyiapan alat dan bahan dilakukan. Penyiapan alat dan bahan ini berupa kegiatan untuk membuat pompa hidram. Untuk memudahkan pembuatan dan kemudahan menjangkau alat dan bahan pembuatan pompa hidram, kegiatan pembuatan pompa dilakukan di Malang karena jika dilakukan di lokasi pengabdian kepada masyarakat, terdapat kendala dalam menyediakan bahan baku pembuatan pompa. Pada kegiatan pembuatan pompa ini, perwakilan warga masyarakat yang terlibat dalam kegiatan pengabdian kepada masyarakat ini dan tukang las didatangkan ke lokasi pembuatan pompa di Malang. Kegiatan pembuatan pompa ini dilaksanakan selama dua hari. Setelah pompa jadi, pompa dibawa ke lokasi pengabdian kepada masyarakat untuk diukur dan dibuatkan dudukan pompanya di sumber air yang akan dialirkan. Pembuatan pompa hidram dapat ditunjukkan pada Gambar 4.
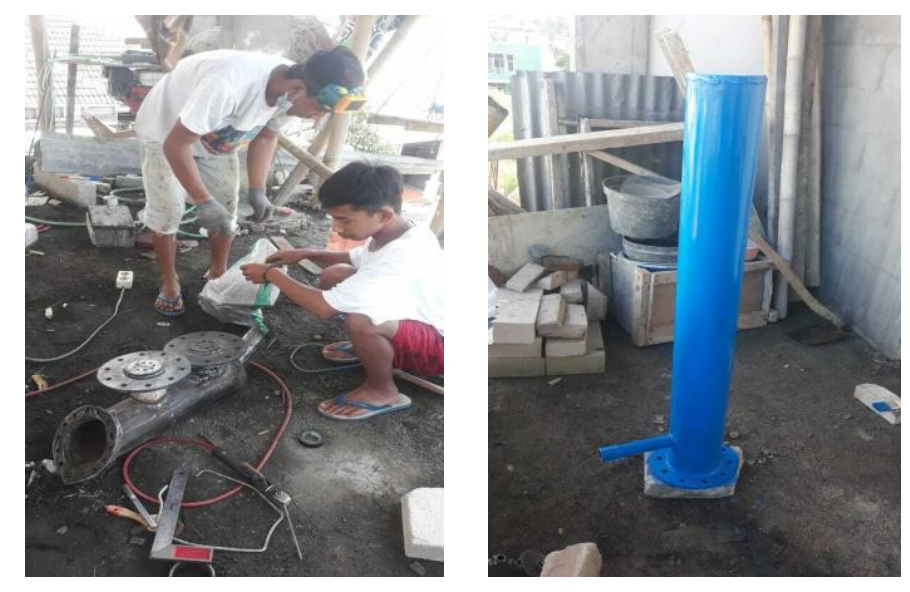

Gambar 4. Pembuatan pompa hidram

Ketiga, pemasangan tandon air. Pemasangan tandon dibagi menjadi dua macam, yaitu tandon utama dan tandon pendukung. Tandon utama digunakan untuk menampung air dari pipa output pompa. Tandon utama ini menampung semua air dari yang dialirkan dari sumber. Selanjutnya, setelah air ditampung di tandon utama, air dialirkan ke tandon-tandon pendukung yang tersebar di beberapa titik rumah warga. Terdapat empat tandon pendukung untuk mendistribusikan air agar wilayah perkampungan warga yang mendapatkan aliran air lebih merata. 
Keempat, perencanaan pengaliran air. Kegiatan perencanaan ini dihadiri oleh tim pengabdian kepada masyarakat, sekretaris desa, kepala sie pembangunan pemerintah kecamatan Lumbang, perwakilan dari Perhutani, dan warga yang dilibatkan dalam program ini. Hal-hal yang dirumuskan pada pertemuan ini adalah (1) waktu pemasangan pipa input dan output, (2) waktu pemasangan pompa, (3) pembentukan tim pengelola air beserta tanggung jawabnya, dan (4) penyadaran literasi hijau kepada masyarakat. Pada kegiatan ini, disepakati bahwa pemasangan pipa dan pompa akan dilaksanakan pada hari Sabtu-Minggu tanggal 3-4 Juli 2021.

Pada pertemuan ini, telah dibentuk tim pengelola air beserta tanggung jawabnya. Tim terdiri atas pengarah, ketua dan wakil tim, penanggung jawab teknis/ pemeliharaan, penanggung jawab keuangan, penanggung jawab hubungan masyarakat. Pembentukan tim ini diharapkan dapat membantu teknis pemeliharaan alat dan menjamin keberlangsungan pengaliran air dalam waktu yang berkesinambungan. Harapannya, setelah kegiatan pengabdian kepada masyarakat ini berakhir, tetap ada pihak yang bertanggung jawab terhadap pengelolaan dan pengaliran air.

Kelima, penyadaran literasi hijau kepada masyarakat. Pada kegiatan ini, dilakukan pula sosialisasi tentang pentingnya menjaga kelestarian lingkungan alam untuk menjaga sumber daya air. Apalagi, isu lingkungan, merupakan salah satu isu penting yang dapat berdampak pada kesejahteraan masyarakat baik secara jangka pendek maupun jangka panjang (Prastiwi, et al., 2021). Masyarakat diberi pemahaman bahwa sumber air akan tetap lestari apabila kelestarian alam juga terjaga. Oleh karena itu, tim yang dibentuk akan bekerja sama dengan pihak Perhutani untuk melakukan penanaman pohon di area sumber air yang dialirkan tersebut.

Untuk memberikan pemahaman tentang teknologi yang digunakan dalam kegiatan pengabdian kepada masyarakat ini, tim pengabdian kepada masyarakat juga memberikan transfer pengetahuan tentang seluk beluk dan cara pemanfaatan pompa hidram. Tim peneliti menjelaskan tentang hakikat pompa hidram yang dapat digunakan untuk mengalirkan air dari lokasi yang lebih rendah ke lokasi yang lebih tinggi dengan ketinggian yang cukup ekstrem. Pada masa sebelumnya, warga hanya mengetahui bahwa air hanya bisa dialirkan dari lokasi yang lebih tinggi ke lokasi yang lebih rendah. Apabila mengalirkan air dari lokasi yang lebih rendah ke lokasi yang lebih tinggi, alat yang dapat digunakan adalah pompa dengan merk Sanyo. Namun, pompa tersebut mempunyai keterbatasan karena tidak dapat digunakan untuk mengalirkan air dari ketinggian ekstrem dengan jarak yang Panjang. Selain itu, diperlukan pula energi listrik untuk mengoperasikan pompa tersebut. Hal ini tentu tidak bisa digunakan untuk mengalirkan air pada sumber air yang menjadi lokasi pengabdian kepada masyarakat ini karena lokasi sumber yang tidak memungkinkan untuk dialiri listrik. Oleh karena itu, tim pengabdian kepada masyarakat menjelaskan bahwa pompa hidram dapat digunakan dalam kondisi yang terjadi pada sumber air yang akan dialirkan tersebut karena pompa hidram dapat digunakan pada lokasi ekstrem tanpa membutuhkan aliran listrik. Proses pemasangan pompa hidram pada lokasi tempat mata air dapat dilihat pada Gambar 5. 

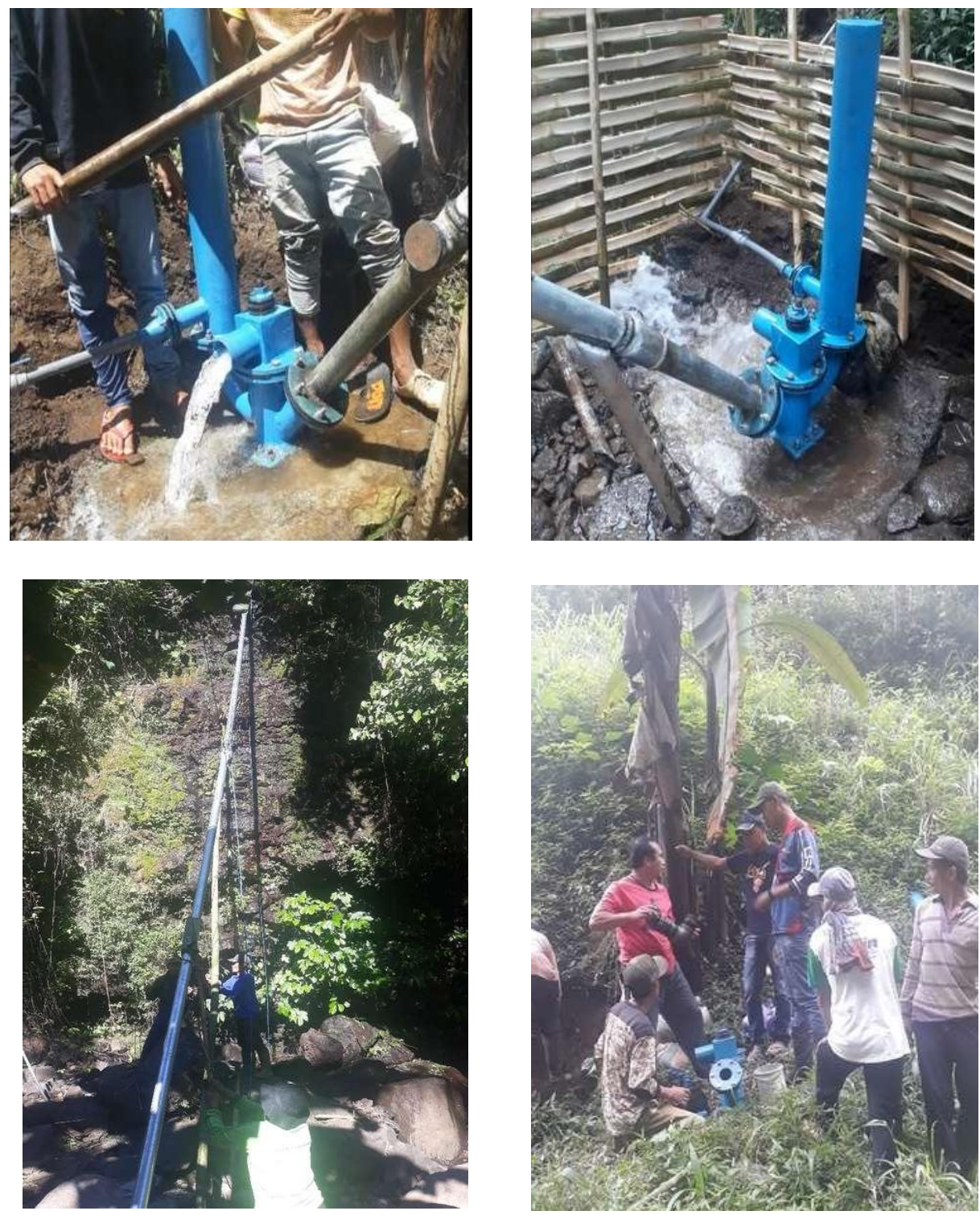

Gambar 5. Pemasangan pompa hidram

Pemberian penjelasan tentang pompa hidram ini penting dilakukan untuk mengenalkan sekaligus meyakinkan masyarakat tentang teknologi yang dibawa oleh tim pengabdian kepada masyarakat. Sebelumnya, mereka belum pernah mengenal teknologi semacam ini sehingga membutuhkan waktu tersendiri untuk lebih meyakinkan masyarakat tentang teknologi yang dibawa ini. Selain itu, pengenalan tentang teknologi ini juga berguna untuk benar-benar memahamkan masyarakat akan teknologi tersebut sehingga jika kegiatan pengabdian kepada masyarakat ini sudah berakhir, masyarakat dapat mengoperasikan atau memelihara pompa hidram tersebut secara mandiri, tanpa harus mendatangkan tim pengabdian kepada masyarakat, dengan demikian, transfer teknologi kepada masyarakat dapat dikatakan berhasil. 


\section{Kesimpulan}

Berdasarkan kegiatan pengabdian kepada masyarakat yang telah dilakukan, dapat disimpulkan sebagai berikut. Pertama, pompa hidram efektif digunakan untuk mengalirkan air dari lokasi sumber air yang lebih rendah ke perkampungan warga di lokasi yang lebih tinggi dengan ketinggian dan jarak yang cukup ekstrem. Kedua, akademisi perlu memberikan transfer teknologi kepada masyarakat karena kendala atau permasalahan yang dihadapi masyarakat sering kali terjadi karena mereka tidak memiliki pengetahuan yang cukup untuk memecahkan masalah tersebut. Ketiga, kegiatan pengaliran air menggunakan pompa hidram di pedesaan dapat berjalan dengan baik sehingga dapat dikatakan bahwa pompa hidram tepat digunakan sebagai sarana menyediakan air bersih di pedesaan. Keempat, selain memanfaatkan sumber daya air yang disediakan oleh alam, penting juga untuk melakukan pelestarian lingkungan sehingga diadakan upaya penyadaran literasi hijau atau penyadaran pentingnya pelestarian lingkungan alam kepada masyarakat.

\section{Acknowledgement}

Kegiatan pengabdian kepada masyarakat ini dilaksanakan dengan pendanaan dari Hibah Penerimaan Negara Bukan Pajak (PNBP). Penulis mengucapkan terima kasih kepada semua pihak yang membantu terlaksananya kegiatan pengabdian kepada masyarakat ini, yaitu masyarakat desa Wonorejo, pemerintah kecamatan Lumbang, Perhutani wilayah Lumbang, mahasiswa dan alumni, serta kolega yang telah berpartisipasi dalam menyukseskan pelaksanaan kegiatan pengabdian kepada masyarakat ini.

\section{Daftar Pustaka}

Anggraeni, T. P., (2019). Pentingnya Membangun Kesadaran Pemeliharaan Lingkungan Guna Menjaga Kelestarian Air Tanah, Jakarta: Universitas Negeri Jakarta.

Audah, K. A. et al., (2019). Penyediaan dan Pemeliharaan Fasilitas Air Bersih dan Sanitasi untuk Peningkatan Kualitas Hidup Masyarakat di Desa Binaan. Prosiding PKMCSR, Volume 2, pp. 516-522.

Fakhrina, A., (2013). Pengelolaan Sumber Daya Air di Dukuh Kaliurang: Perspektif Ekonomi Islam. Jurnal Penelitian, 9(1), pp. 1-17. https://doi.org/10.28918 /jupe.v9i1.127.

Fatikh, M. A. \& Panuju, R., (2018). Komunikasi Organisasi Kehumasan Polres Pasuruan. Jurnal Riset Komunikasi, 1(1), pp. 22-34. http:/ / dx.doi.org/10.24329/jurkom.v1i1.8.

Herlambang, A. \& Wahjono, H. D., (2006). Rancang Bangun Pompa Hidram untuk Masyarakat Pedesaan. Jurnal Air Indonesia, 2(2), pp. 178-186. https:// doi.org/10.29122/jai.v2i2.2309.

Kodoatie, R., (2005). Kajian Undang-Undang Sumber Daya Air. Yogyakarta: Penerbit Andi. 
Kuncoro, W. \& Wangi, W., (2021). Sosialisasi Penggunaan Pompa Hidram dalam Mengoptimalisasi Pengairan Lahan di Atas Permukaan Sungai. JURPIKAT(Jurnal Pengabdian Kepada Masyarakat), 2(1), pp. 77-87. https://doi.org/0.37339 /jurpikat.v2i1.482.

Kurniawan, D., Sholichin, M. \& Cahya, E., (2018). Studi Perencanaan Distribusi Air Bersih di Kecamatan Lumbang Kabupaten Pasuruan Menggunakan Program Watergems V8I. Jurnal Mahasiswa Teknik Pengairan, 1(2), pp. 58-68. http:// pengairan.studentjournal.ub.ac.id/index.php/jmtp/article/view/83/58.

Prastiwi, J. H., Susanti, A. \& Yunas, N. S., (2021). Penyusunan Draft Rancangan Peraturan Desa "Kampung Sehat" Berbasis Partisipasi Warga di Desa Plosokidul Kabupaten Kediri. Surya Abdimas, 5(3), pp. 251-262.

Pribadi, D. T., (2019). Rancangan Pembangkit Listrik Tenaga Air Menggunakan Pompa Hidram Untuk Kebutuhan Rumah Tangga. Repository Unsu.

Sukamta, et al., (2019). Peningkatan Kemandirian Desa melalui Pembangunan Instalasi Perpipaan Air Bersih dari Sumber Mata Air ke Rumah Penduduk. Jurnal BERDIKARI, 7(1), pp. 14-21. https:// doi.org/10.18196/bdr.7152.

Suyeno, Wijaya, A. F. \& Hanafi, I., 2014. Implementasi Kebijakan Pelayanan Air Bersih Wilayah Perkotaan Berbasis Kerja Sama Pemerintah dan Swasta di Kecamatan Mandau. Wacana, 17(1), pp. 21-24.

Utomo, G. \& Supardi, E., 2015. Analisa Pengaruh Tinggi Jatuhan Air terhadap Head Pompa Hidram. Jurnal Pengabdian LPPM Untag, 1(2), pp. 211-224.

Widarto, L. \& Sudarto, F., 2000. Teknologi Tepat Guna: Membuat Pompa Hidram. Yogyakarta: Kanisius.

Zulfiar, M. H., 2020. Penerapan Teknologi Pompa Hidram bagi Masyarakat Pedesaan. Jurnal BERDIKARI, 2(1), pp. 1-12. https:/ / doi.org/10.18196/bdr.8171. 